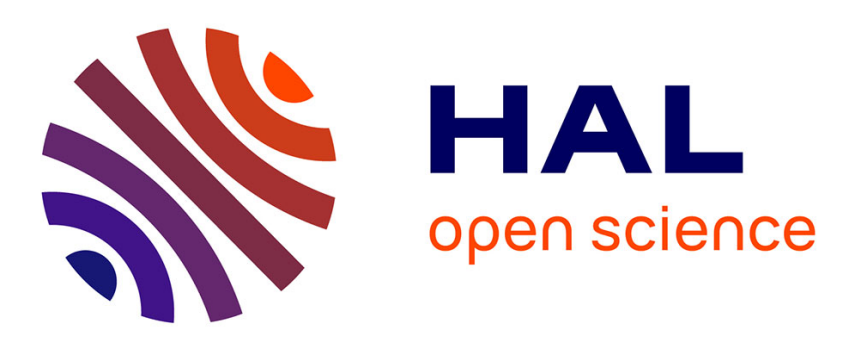

\title{
Jacques Lacan and game theory: an early contribution to common knowledge reasoning
}

Pierre Courtois, Tarik Tazdaït

\section{To cite this version:}

Pierre Courtois, Tarik Tazdaït. Jacques Lacan and game theory: an early contribution to common knowledge reasoning. European Journal of the History of Economic Thought, 2021, 28 (5), pp.844-869. 10.1080/09672567.2021.1908392 . hal-03179414

\section{HAL Id: hal-03179414 \\ https://hal.inrae.fr/hal-03179414}

Submitted on 8 Dec 2021

HAL is a multi-disciplinary open access archive for the deposit and dissemination of scientific research documents, whether they are published or not. The documents may come from teaching and research institutions in France or abroad, or from public or private research centers.
L'archive ouverte pluridisciplinaire HAL, est destinée au dépôt et à la diffusion de documents scientifiques de niveau recherche, publiés ou non, émanant des établissements d'enseignement et de recherche français ou étrangers, des laboratoires publics ou privés. 


\title{
Jacques Lacan and Game Theory:
}

\section{An early contribution to common knowledge reasoning}

\author{
Pierre Courtois ${ }^{\mathrm{a}}$ and Tarik Tazdaït $\mathrm{b}^{\mathrm{b}}$
}

\begin{abstract}
Lacan's contribution in applying and promoting game theory in the early 1950s is mostly ignored in the history of game theory. Yet his early analyses of logical reasoning made him one of the first social scientists to consider the importance of the hypothesis of common knowledge. By retracing Lacan's path in his discovery of game theory, we show how much he has been a precursor in applying it. While accommodating a narrative approach, he demonstrated rigor and originality. Soliciting mathematicians open to interdisciplinarity, he introduced as early as 1945 modes of reasoning which corresponds to reasoning based on common knowledge.
\end{abstract}

Keywords: Lacan, common knowledge, enigma of the three prisoners, la Lettre Volée

JEL Codes: B16, C72

\section{Introduction}

Game theory is one of the most widespread mathematical approaches in the social sciences today. Originally regarded as mathematics for economics, it eventually crossed disciplinary boundaries and is now applied among others in political science, psychology and sociology. If game theory is now established, this was far from being the case in the early 1950s when only a few mathematicians and military strategists got interested in its development (Leonard 2010). Among economists, poor attention was given to the approach as it was yet little theoretical ground to promote applications.

Interestingly, one of the few social scientists interested in applying game theory in the 1950s was Jacques Lacan, a psychoanalyst. Although John von Neumann (co-author with Oskar Morgenstern

\footnotetext{
${ }^{a}$ CEE-M, Univ. Montpellier, CNRS, INRAe, Instit. Agro, Montpellier, France

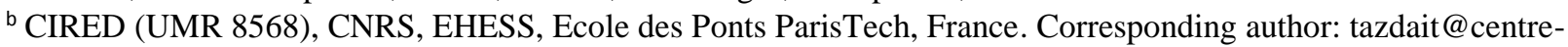
cired.fr
} 
of the famous Theory of Games and Economic Behavior published in 1944) had close relationships with Sandor Ferenczy ${ }^{1}$, a psychoanalyst and disciple of Sigmund Freud, there is no indication that he saw the unconscious as a potential field of application of game theory. What makes Lacan's contribution outstanding is not only he was a psychoanalyst but he was among the first to promote the theory by giving it life through applications. Like Freud and most psychoanalysts of his generation, Lacan had a medical background with a specialization in neurology. This made him able to possess a certain openness towards mathematical applications. The originality of his work at the time lies in the fact that the questions he analyzed go well beyond the field of psychoanalysis and concern other social sciences and in particular game theory, as these questions are directly related to an important characteristic of game theory, namely the hypothesis of common knowledge. It is nevertheless surprising that such work has not had an echo in its time and that it is only belatedly coming to our knowledge. There are several reasons for this. First of all, during the period that interests us, that is, from 1945 to 1957, Lacan, while having a writing activity, largely devoted himself to his medical profession as a liberal psychoanalyst and thus did not give himself the time to promote his work. It should also be emphasized that being outside of any academic institution, Lacan did not train students who could have contributed to the diffusion and extension of his work. Moreover, during this same period, he did not enjoy unanimity among psychoanalysts: while he sought to reinterpret Freud, he was marginalized and few of his peers were really interested in his work ${ }^{2}$. Moreover, his reflections on logical reasoning in social interactions were published in French in specialized journals that were not necessarily adapted to the content of his work, which hindered their visibility. For example, his "enigma of

\footnotetext{
1 "Hungary's famed father of the modern computer, John von Neumann, and his family were on very good terms with Ferenczy, and psychoanalysis was as natural a topic at dinner as economics or mathematics" (Meszaros 2012, 80).

${ }^{2}$ Note that it was in order to break out of his isolation that Lacan created in 1953 a public seminary which was held at the Sainte-Anne hospital until 1963 and which, with the help of the philosopher Louis Althusser, was next transferred to the Ecole normale supérieure in the rue d'Ulm. It was later called the "Lacan's Seminar".
} 
the three prisoners" (in which he resorts to an original mode of reasoning for the time) appeared in 1945 in an artistic and literary review, Les Cahiers d'Art, which was an astonishing editorial choice given the content of the article. Finally, when the literature on common knowledge and then epistemic logic began to develop in the late 1960s for the former and in the late 1970s for the latter, Lacan had already turned his back on game theory and aimed to develop his analyses by relying on graph theory and topology.

In this article, which follows Antoine Billot (2006) and Rabia Nessah et al. (2021), we focus on Lacan's work in relation to the hypothesis of common knowledge. We return to how Lacan arrived at game theory and how he appropriated the principles of game theory and the underlying hypothesis. Lacan's work on common knowledge aimed at giving a rigorous basis to other psychanalysis notions such as, for example, the notions of "logical time" or of "repetition automatism". We will not, however, go into detail on these notions, which are more a matter for the history of psychoanalytical thought. Rather, we will focus on its contributions to strategic reasoning through its original use of common knowledge. As we shall see, even if this is not yet recognized, Lacan has a place in the history of game theory and thus in the history of economic thoughts.

The paper proceeds as follows. Section (2) presents the enigma of the three prisoners which is Lacan's first application of common knowledge. ${ }^{3}$ This game is the starting point of Lacan's commitment to game theory. We argue how starting from this game, Lacan gradually became acquainted with game theory, surrounding himself with mathematicians to advise him. Section (3) exhaustively discusses a session of his seminar held on 26 April 1955, known as the seminar on "La Lettre Volée" ("The Purloined Letter"). In this seminar, he will once again apply common

\footnotetext{
${ }^{3}$ This game is to be distinguished from the "problem of three prisoners" which happens to be a bayesian problem introduced by Frederick Mosteller (1965).
} 
knowledge, underlining his commitment to this mode of reasoning and the importance that he gives to it for strategic thinking. Section (4) concludes.

\section{Lacan's mode of reasoning and his progressive use of game theoretic reasoning}

\subsection{First steps towards the analysis of games}

After an intense writing activity that led him to publish nearly 40 articles on the period 19261938, Lacan interrupted it during the Second World War. He signed his return with two articles published successively in Les Cahiers d'Art in 1945 and in 1946. These papers mark a break with his previous writings as they do not deal with practical issues of psychiatry and psychoanalysis but problems of logic from which lessons are drawn for psychoanalysis. Lacan argues in these two papers on the need to nourish psychoanalysis with formal approaches. The first, entitled "Le Temps Logique et l'Assertion de Certitude Anticipée. Un Nouveau Sophisme” ("Logical Time and the Assertion of Anticipated Certainty. A New Sophism"), is a logical analysis of agents' anticipation. The second, entitled "Le Nombre Treize et la Forme Logique de la Suspicion" ("The Number Thirteen and the Logical Form of Suspicion"), deals with a recreational mathematics problem. Although published in 1946, this later paper was written before the former (Porge 2000). However, we learn from Lacan (1946) that the recreational mathematics problem to which he refers to had been developed by the mathematician François Le Lionnais. He also states that he was informed of it through the intermediary of the writer Raymond Queneau. Thus, everything suggests that it was in contact with Queneau that Lacan decided to pay some attention to mathematics; Queneau himself being a literary lover of mathematics.

In his 1945 paper, Lacan defines an enigma we refer to as the enigma of the three prisoners. He solves it using reasoning we can assimilate to common knowledge reasoning. In this work, no 
reference is made to common knowledge which can easily be understood as this notion was not defined nor really investigated at the time. According to Peter Vanderschraaf and Giacomo Sillari (2014), the sociologist Morris Friedell $(1967,1969)$ and the philosopher David Lewis (1969) were the first to define common knowledge in a syntactic logical framework. While Friedell (1969) offers a detailed example to emphasize the importance of common knowledge in the study of a two-player zero-sum game, Lewis applies the hypothesis to study the rationality of conventions. It should be noted that Thomas Schelling (1960) had, prior to this work, suggested the cognitive phenomenon at work in coordination games. By emphasizing specularity in the resolution of coordination situations, he indirectly showed the necessity of the hypothesis of common knowledge. Independently of these early works, several authors proposed alternative definitions, including Stephen Schiffer (1972), Robert Aumann (1976) and Gilbert Harman (1977). Aumann (1976) in particular proposed the first mathematical formalization of common knowledge, which he developed in a set-theoretic approach.

Without apparently being aware of it, Lacan, in his 1945 paper, let himself be guided by a mode of reflection impregnated with the philosophy of game theory. He analyses a game situation considering a logical mode of reasoning that is fully related to game theory thinking. The true aim of his paper is to show that "the collective is nothing but the subject of the individual"4 (2006b [1966], 175). Here the term "collective" should not be taken in its usual sense as it does not refer to a community or a group but to individuals with divergent interests (not to say adversaries). In this sense, Lacan's sentence suggests that it is with regard to what is anticipated of the behaviour of others that each one determines his own behaviour, which is in line with what game theory proposes to model. To give meaning to his thesis, he relies on a story (which he presents as a new

\footnotetext{
${ }^{4}$ Note that this sentence does not appear in the original 1945 version. Lacan added it in the version which appears in his main theoretical work published in 1966, Écrits. We can think that it is after having noticed the link between his article and game theory that he added it.
} 
sophism) whose plot concerns three prisoners who see the prison director telling them the following:

\begin{abstract}
"There are three of you present. I have here five disks differing only in color: three white and two black. Without letting you know which I will have chosen, I will fasten one of them to each of you between the shoulders, outside, that is, your direct visual fieldindirect ways of getting a look at the disk also being excluded by the absence here of any means by which to see your own reflection.

You will then be left at your leisure to consider your companions and their respective disks, without being allowed, of course, to communicate among yourselves the results of your inspection. Your own interest would, in any case, proscribe such communication, for the first to be able to deduce his own color will be the one to benefit from the discharging measure at my disposal.

But his conclusion must be founded upon logical and not simply probabilistic grounds. Keeping this in mind, it is agreed that as soon as one of you is ready to formulate such a conclusion, he will pass through this door so that he may be judged individually on the basis of his response" (Lacan 2006b [1966], 161-162). ${ }^{5}$
\end{abstract}

Given these rules, it is assumed that each of the prisoners is then adorned with a white disk. To determine the solution of this enigma and, by the same token, the behavior of each prisoner, it is proposed to adopt the point of view of one of the prisoners whose choice is established according to the following reasoning:

"I am a white, and here is how I know it. Since my companions were whites, I thought that, had I been a black, each of them would have been able to infer the following: "If I too were a black, the other would have necessarily realized straight away that he was a white and would have left immediately; therefore, I am not a black." And both would have left together, convinced they were whites. As they did nothing of the kind, I must be a white like them. At that, I made for the door to make my conclusion known" (Lacan 2006b [1966], 162). ${ }^{6}$

As the reasoning of the prisoner is valid for each of the others, each one is then led to infer that the disk which he carries is white that is why all will pass the door simultaneously to announce their answer?

Insofar as the "collective" was represented by a given number of prisoners, Lacan claims that this enigma can be generalized to any number of subjects. For this, a condition must nevertheless be

\footnotetext{
${ }^{5}$ In the French version, see Lacan (1966, 197-198).

${ }^{6}$ In the French version, see Lacan $(1966,198)$.

${ }^{7}$ For the Lacan's proof, see Annex.
} 
verified, in particular, the negative attribute (here the black disk) must intervene "in a number equal to the number of subjects minus one" $\left(2006 \mathrm{~b}\right.$ [1966], 174) ${ }^{8}$. To convince us, he analyses succinctly the case of four prisoners, four white disks and three red disks. He shows that the reasoning is perfectly similar.

Common knowledge reasoning is made paramount in solving this enigma because of the information dispatched by the prison director on the distribution of disk colors. It is true that this does not come out blatantly insofar as the information he delivers on the distribution of the disks does not seem to constitute major information. But by publicly announcing the distribution of the disks, he tells the prisoners that at least one white disk is worn while each of them knows it since each observes that at least one white disk is worn. Yet it is at this level that the director's position takes on its full meaning: if he had not made the distribution of the disks public, none of the prisoners would have been able to determine the color of the disk he was wearing.

To see it more carefully, let us distinguish the prisoners by denoting them $i, j$ and $k$, and place ourselves, for example, from the point of view of $i$. In the absence of an announcement from the director, $i$ still sees that $j$ and $k$ are adorned with a white disk. He knows that there are two or three prisoners wearing a white disk. He also knows that $j$ sees one or two prisoners wearing a white disk and $k$ sees one or two prisoners wearing a white disk. Let us add that for $i$, if $j$ (resp. $k$ ) sees two prisoners wearing a white disk, then he knows that $j$ (resp. $k$ ) thinks that $k$ (resp. $j$ ) sees one or two prisoners wearing a white disk. Similarly, for $i$, if $j$ (resp. $k$ ) only sees a prisoner wearing a white disk, then he knows that $j$ (resp. $k$ ) thinks that $k$ (resp. $j$ ) sees none or one prisoner wearing a white disk. However, on the basis of this argument, it is not possible for $i$ to determine the color of the disk he wears. The explanation is the following: observing that $j$ and $k$ wear a white disk, $i$

\footnotetext{
${ }^{8}$ In the French version, see Lacan (1966, 212-213).
} 
knows that at least one white disk is worn, but he does not know if $j$ (resp. $k$ ) knows that $k$ (resp. j) knows that at least one white disk is worn. This limit in the argument is also valid if one had considered the reasoning from the point of view of $j$ or $k$.

It is the announcement that the director makes about the distribution of the disks that allows the prisoners to carry out their reasoning. Indeed, this announcement guarantees that it will be common knowledge that at least one of the white disks is worn. Thus, through his announcement, the director comes to create common knowledge. Remember that for an event to be common knowledge, it is not only necessary for everyone to know it, everyone must also know that everyone knows it, and everyone knows that everyone knows that everyone knows it, and so on. Aumann (1976), who is at the origin of this definition, also proposed a formalization of common knowledge (in terms of the states of the world) which makes it possible to study its implications. As Billot (2008) points out, since Lacan based his reasoning on specularity, it is then possible to account for the enigma using the formal framework defined by Aumann (1976). Billot's demonstration is the following. ${ }^{9}$ As a state of the world describes the color of each prisoner's disk, there are eight possible states of the world as indicated below where $\mathrm{W}$ (resp. B) denotes a white (resp. a black) disk.

States of the world

\begin{tabular}{llllllllll}
\multirow{5}{*}{ Prisoner } & $i$ & W & W & W & W & B & B & B & B \\
& $j$ & W & W & B & B & W & W & B & B \\
& $k$ & W & B & W & B & W & B & W & B
\end{tabular}

In the absence of an announcement from the director, prisoners do not know the distribution of disk colors. Each observes the disks worn by the others but does not know the color of the disk he is wearing. The partitions of the three prisoners (which correspond to what the prisoners could

\footnotetext{
${ }^{9}$ We thank Philippe Solal and Bertrand Crettez for making us aware of the existence of Billot's paper (2008).
} 
know at the outset) are given by:

$$
\begin{aligned}
& \mathrm{P}_{\mathrm{i}}=\{(\mathrm{WWW}),(\mathrm{BWW})\}-\{(\mathrm{WWB}),(\mathrm{BWB})\}-\{(\mathrm{WBW}),(\mathrm{BBW})\}-\{(\mathrm{WBB}),(\mathrm{BBB})\} \\
& \mathrm{P}_{\mathrm{j}}=\{(\underline{\mathrm{WWW}}),(\mathrm{WBW})\}-\{(\mathrm{WWB}),(\mathrm{WBB})\}-\{(\mathrm{BWW}),(\mathrm{BBW})\}-\{(\mathrm{BWB}),(\mathrm{BBB})\} \\
& \mathrm{P}_{\mathrm{k}}=\{(\underline{\mathrm{WWW}}),(\underline{\mathrm{WWB}})\}-\{(\mathrm{WBW}),(\mathrm{WBB})\}-\{(\mathrm{BWW}),(\mathrm{BWB})\}-\{(\mathrm{BBW}),(\mathrm{BBB})\}
\end{aligned}
$$

We underline states that each of the prisoners observes when the actual state is (WWW). Prisoner $i$ observes that the two other prisoners wear a white disk but do not know whether himself wears a white or a black disk and cannot, therefore, distinguish (WWW) from (BWW). Similarly, when the actual state is (WWW), prisoner $j$ cannot distinguish (WWW) from (WBW) and prisoner $k$ (WWW) from (WWB).

Following the director's announcement on the distribution of the disks, it becomes common knowledge that each prisoner can distinguish the state (BBB) from all the others. As a result, it becomes common knowledge of the three prisoners that the partitions write:

$$
\begin{aligned}
& \mathrm{P}_{\mathrm{i}}=\{(\underline{\mathrm{WWW}}),(\underline{\mathrm{BWW}})\}-\{(\mathrm{WWB}),(\mathrm{BWB})\}-\{(\mathrm{WBW}),(\mathrm{BBW})\}-\{(\mathrm{WBB})\}-\{(\mathrm{BBB})\} \\
& \mathrm{P}_{\mathrm{j}}=\{(\underline{\mathrm{WWW}}),(\underline{\mathrm{WBW}})\}-\{(\mathrm{WWB}),(\mathrm{WBB})\}-\{(\mathrm{BWW}),(\mathrm{BBW})\}-\{(\mathrm{BWB})\}-\{(\mathrm{BBB})\} \\
& \mathrm{P}_{\mathrm{k}}=\{(\underline{\mathrm{WWW}}),(\underline{\mathrm{WWB}})\}-\{(\mathrm{WBW}),(\mathrm{WBB})\}-\{(\mathrm{BWW}),(\mathrm{BWB})\}-\{(\mathrm{BBW})\}-\{(\mathrm{BBB})\}
\end{aligned}
$$

Because by assumption there is only two black disks, prisoner $i$ induces the color of his disk in the states $(\mathrm{WBB})$ and $(\mathrm{BBB})$, prisoner $j$ in the states $(\mathrm{BWB})$ and $(\mathrm{BBB})$, and prisoner $k$ in the states $(\mathrm{BBW})$ and (BBB). This information is common knowledge, meaning that if states (WBB), (BWB) or (BBW) are drawn, then everyone knows that one prisoner will leave the room immediately. Partitions then write:

$$
\begin{aligned}
& \mathrm{P}_{\mathrm{i}}=\{(\mathrm{WWW}),(\underline{\mathrm{BWW}})\}-\{(\mathrm{WWB})\}-\{(\mathrm{BWB})\}-\{(\mathrm{WBW})\}-\{(\mathrm{BBW})\}-\{(\mathrm{WBB})\}-\{(\mathrm{BBB})\} \\
& \mathrm{P}_{\mathrm{j}}=\{(\underline{\mathrm{WWW}}),(\underline{\mathrm{WBW}})\}-\{(\mathrm{WWB})\}-\{(\mathrm{WBB})\}-\{(\mathrm{BWW})\}-\{(\mathrm{BBW})\}-\{(\mathrm{BWB})\}-\{(\mathrm{BBB})\} \\
& \mathrm{P}_{\mathrm{k}}=\{(\underline{\mathrm{WWW}}),(\underline{\mathrm{WWB}})\}-\{(\mathrm{WBW})\}-\{(\mathrm{WBB})\}-\{(\mathrm{BWW})\}-\{(\mathrm{BWB})\}-\{(\mathrm{BBW})\}-\{(\mathrm{BBB})\}
\end{aligned}
$$

At that point, everyone knows that prisoner $i$ cannot distinguish between states (WWW) and (BWW), prisoner $j$ between states (WWW) and (WBW) and prisoner $k$ between states (WWW) and (WWB). Placing ourselves from the point of view of one of the prisoners, say prisoner $i$, we know that if prisoner $j$ does not leave the room, this is because he does not know whether he is in state (WWW) or (WBW). Similarly, if prisoner $k$ does not leave the room, this is because he is either in state (WWW) or (WWB). Prisoner $i$ then induces that the state of the world is necessarily (WWW) and he should leave the room immediately. Partitions write: 
$P_{i}=\{(\underline{W W W})\}-\{(\underline{B W W})\}-\{($ WWB $)\}-\{(B W B)\}-\{($ WBW $)\}-\{($ BBW $)\}-\{(\mathrm{WBB})\}-\{(\mathrm{BBB})\}$

$P_{j}=\{(\underline{W W W}),($ WBW $)\}-\{($ WWB $)\}-\{($ WBB $)\}-\{($ BWW $)\}-\{(\mathrm{BBW})\}-\{(\mathrm{BWB})\}-\{(\mathrm{BBB})\}$

$\mathrm{P}_{\mathrm{k}}=\{(\underline{\mathrm{WWW}}),(\underline{\mathrm{WWB}})\}-\{(\mathrm{WBW})\}-\{(\mathrm{WBB})\}-\{(\mathrm{BWW})\}-\{(\mathrm{BWB})\}-\{(\mathrm{BBW})\}-\{(\mathrm{BBB})\}$

Since the game is static and prisoners' $j$ and $k$ reason in the same way as $i$, they all end up inducing simultaneously that the real world is (WWW) and thus leave the room simultaneously.

Although Lacan's argumentation is of a narrative nature, it leads to the formal result highlighted by Billot, which is not surprising given that his thinking is based on a hypothetico-deductive method. One finds in Lacan's argumentation, moreover, the specularity inherent in common knowledge, "that is the mental act by which an individual decides to put himself in the place of another in order to experiment virtually his reasoning within a game" (Billot 2008, 117). Finally, Lacan equates the prisoners' mode of reasoning with reasoning based on logic, and his enigma seems to him so interwoven in the domain of logic that the words "logic" or "logically" appear redundantly in his article about eighty times. For him, it is this logical reasoning that leads each prisoner to anticipate with certainty the color of the disc he is wearing, hence the expression "anticipated certainty" in the title. This is precisely what common knowledge allows: to anticipate with certainty. What Lacan considers to be logical reasoning corresponds in fact to reasoning based on common knowledge. It is moreover interesting to note that Lacan insists that "the subjectivization $[. .$.$] which takes from here in the 'one knows that ..."' is too impersonal, which is$ why in the discussion he opens around his results, he prefers to rely on a presentation in terms of 'Being ..., only then does one know that one is ...' (Lacan 2006b [1966], 167) ${ }^{10}$.

We must now explain what makes Lacan's article outstanding. As John Geanakoplos (1994) and Vanderschraaf and Sillari (2014) note, the first examples of common-knowledge-type reasoning were proposed by John Littlewood (1953), then by George Gamow and Marvin Stern (1958),

\footnotetext{
${ }^{10}$ In the French version, see Lacan $(1966,205)$.
} 
notably with the example of the "forty unfaithful women". It is only much later that formalization frameworks were developed. Given the anteriority of Lacan's article (and the state of knowledge), we can situate his work in the literature as the first game reasoning based on common knowledge, another good albeit complementary candidate being Morgenstern (1976 [1935]) in his analysis of unlimited forsight and economic equilibrium.

Interestingly, because of the director's position, Lacan's enigma reveals logical characteristics that are close to the well known "red hat game" that was inspired by Littlewood (1953). Although sequential, the "red hat game" finds many analogies with the three prisoners enigma. It proceeds as follows. Three children sit in a circle in a room and a teacher places a hat on each child's head explaining that it can be red or white. In reality, all of them wear a red hat but obviously, children do not know it. Each child sees the hat worn by the others but cannot see his own. When the teacher asks each child successively if he knows the color of the hat he is wearing, each one in turn answers in the negative since none of them sees the hat he is wearing.

Suppose that the teacher publicly announces that at least one of the hats worn is red. Again, we could say that the information provided by the teacher does not seem essential since children are told that at least one of them wears a red hat which each of them was already observing.

Yet, as we can show, it impacts the result. By asking the first child again whether he knows the color of his hat, he cannot answer. The same applies to the second child when the question is asked. Only the third is able to find out that his hat is red. Indeed, the first child sees two red hats (and therefore sees that there is at least one red hat worn) but cannot deduce anything about the color of his own hat. Eventually, the other two children know that the first did not see two white hats because if this had been the case, given the information provided by the teacher, he would 
have been able to determine with certainty the color of his own hat. So they know that one of them is wearing a red hat. When it is the second child's turn to answer the question, he too cannot give an answer because he observes a red hat on the third child's head and this does not allow him to deduce the color of his own hat. When the third one has to answer, he knows that if he was wearing a white hat, the second child would have deduced that he is the one wearing a red hat and would have given the answer to the question asked. Since the second child did not give any answer, the third child infers that he did not observe a white hat and then knows that he does wear a red hat. Thus, as with Lacan's enigma, the outcome of the "red hat game" is solved from the public announcement by the teacher who comes to make common knowledge the information that at least one of the hats worn is red.

Note that the enigma of the three prisoners is quoted today by several philosophers and mathematicians. However, it is never mentioned in game theory textbooks to illustrate common knowledge. Despite its posteriority and its proximity to Lacan's enigma, textbooks usually resort to the "red hat game". This apparent paradox finds two explanations. The first is that Lacan was foremost interested in mental states and belief hierarchies rather than equilibrium analysis which certainly made his work less attractive to game theorists (epistemic game theory came up much later, see Guilhem Lecouteux (2018)). The second explanation is that authors quoting Lacan's enigma present it as having been introduced in 1966 (instead of 1945) which certainly contributed to its limited resonance in the scientific community. No reference at all is made to the original 1945 article, whereas at the end of the 1966 contribution is included a bibliographical list referencing the original articles composing the collection. ${ }^{11}$ For example, Frédéric Koessler (2000, 285) mentions Lacan's enigma in a footnote in relation to the red hat game: “see Littlewood (1953)

\footnotetext{
${ }^{11}$ On page 917 of the French version of Écrits published in 1966, Lacan notes "Le temps logique et l'assertion de la certitude anticipée. This paper was written in March 1945. Published in the Cahiers d'Art: 1940-1945". In the English translation, we find this mention on page 864 .
} 
and Lacan (1966) for ones of the earliest versions of this example". Similarly, Jean-Pierre Dupuy $(1989,397)$ quotes Lacan's enigma referring to the 1966 book. He describes the enigma in a very concise manner as follows:

\begin{abstract}
"Consider the example of the three prisoners, dear to J. Lacan (1966). Three condemned to death in a cell, each with a black disc on his back; they know that these discs were taken from a batch of three blacks and two whites. The first to discover the color of his disc must leave the cell. Everyone is immersed in the specular game, relying solely on the fact that, apart from the data, is common knowledge the others do not move. Everyone thinks he's discovering the color of his disk, he goes forward to signify it and, at that precise moment, his premise collapses since everyone does the same at the same moment".
\end{abstract}

This is interesting to note that Dupuy does not offer any element of appreciation as to the reasoning behind the result. This is as if he considered that Lacan's enigma was known to everyone. No mention is made of the fact that this enigma is one of the first if not the first example referring explicitly to the idea underlying common knowledge ${ }^{12}$.

In fact, Dupuy quotes the enigma in order to argue that in complete and perfect information settings, common knowledge can lead individuals to a dead end. Furthermore, because only one of the prisoners was to be released and all three of them have the right answer, it is then impossible for the director to respond to the request to release a single prisoner. It is in this paradox (created by the director himself) that Dupuy (1989) sees a dead end. But is it really a dead end resulting from common knowledge? Another, albeit simpler explanation is that the rules defined by the prison director reflect his preferences, i.e. he is asked to release a prisoner when he does not wish to do so? He would thus have proposed rules of the game that would lead to the result he is seeking. This question remains completely open and in any event, the reason Lacan introduces this example is not a priori to discuss this paradox but rather to analyze the impact of knowledge and reasoning on decisions.

\footnotetext{
12 Others such as Michel Plon (1976) and Nathalie Charraud (1997) refer also to Lacan's enigma using the 1966 quote and make no mention of the original 1945 version. Jean-Pierre Cléro (2008) even refer to it quoting the 1999 edition of Écrits.
} 
Lacan's mode of reasoning led him later to invest in game theory. However, he took the time to become aware of the link between his article and game theory. In 1945, the work of von Neumann and Morgenstern had not reach France yet. Slowly but surely, under the impulse among others of the writings of the psychologist Jean Piaget (1945) on the educational function of games, of the sociologist Roger Caillois (1946) on the relationship between games and the sacred, and of the linguist Emile Benveniste (1947) on the function of games in society, the notion of games started to take an important role in social sciences. While games had long been the sole object of mathematicians through their interest in "board games", it has become an object of the social sciences which has contributed to placing social sciences between literature and hard sciences. Studies on the structure of games (sports games, board games) and their cultural significance came out in the 1950s and 1960s. This is the case for instance with Caillois (1958) who, in line with Johan Huizinga (1951 [1938]), attempted to propose a general theory of the evolution of human societies by showing how much games contribute to transforming instinct into social. These works are not directly related to game theory but they contributed, in their own way, to creating a favorable climate for the reception of game theory.

\subsection{The Path to Game Theory}

Lacan interest in game theory came from his close relationship with mathematicians he met thanks to Claude Lévi-Strauss. This last, who had lived through the war in exile in New York, returned to France convinced that the future of social sciences laid in the use of mathematics. This conviction was totally consistent with Lacan's belief that mathematics had a role to play in psychoanalysis, even if he did not know yet what field of mathematics to use. From their meeting in 1949, through a mutual friend, the philosopher Alexandre Koyré, they set out to find researchers best able to help them in their respective fields (Bertholet 2008; Lévi-Strauss and Eribon 2009). 
Lévi-Strauss had taken advantage of his exile to write his thesis, "Les Structures Elémentaires de la Parenté" (“The Elementary Structures of Kinship”). In preparing the chapters devoted to Australia, he found himself confronted with particularly sophisticated laws of marriage (of an aboriginal community living in Arnhem Land, the Murngin). The problem seemed so complex that he came to the conclusion that only mathematicians could solve it. He then contacted Jacques Hadamard, also exiled in New York, who replied: "mathematics knows only four operations and marriage cannot be assimilated to any one" (Lévi-Strauss and Eribon 2009, 79). Hadamard's answer is quite categorical: since marriage is not a mathematical object, mathematical analysis cannot be made. Following this failure, Lévi-Strauss contacted another French exile, André Weil, a founding member of Bourbaki. Weil agreed to study the problem, stressing that " $\mathrm{t}]$ here is no need to define marriage mathematically. Only the relationship between marriage is of interest" (Lévi-Strauss and Eribon 2009, 79). He thus gave a solution to the problem posed by resorting to group theory; which appears in the appendix of chapter 14 of the version of Lévi-Strauss thesis published in 1949. This solution has had such an impact that it opened a research path among mathematicians and ethnologists, who further proposed generalizations ${ }^{13}$.

This success contributed to convincing Lévi-Strauss of the appeal of mathematics. It explains why, on his return to France, he surrounded himself with mathematicians. As shown in his correspondence with the linguist Roman Jakobson, whom he had met in the United States, LéviStrauss benefited from Marcel-Paul Schützenberger's support to work on systems theory (Jakobson and Lévi-Strauss, 2018) ${ }^{14}$. He was also in contact with Benoît Mandelbrot whom he described as being "convinced that the ideas of von Neumann (Theory of Games) are capable of

\footnotetext{
${ }^{13}$ See, among others, Robert Bush (1963), Harrison White (1963), Philippe Courrège (1965), Russell Reid (1967) and John Boyd (1969).

${ }^{14}$ This reference corresponds to a letter from Lévi-Strauss dated 15 March 1951.
} 
great applications in linguistics" (Jakobson and Lévi-Strauss 2018, 147) ${ }^{15}$. A letter dated $13^{\text {th }}$ March 1952 shows that he also had links with Jacques Riguet, whom he described as "a very brilliant young mathematician" (Jakobson and Lévi-Strauss 2018, 150). Finally, Lévi-Strauss and Lacan contacted Georges-Théodule Guilbaud in 1951 in order to learn more about the possible relationships between mathematics and social sciences, several working sessions were organized in the process (Roudinesco 2010; Nessah et al. 2021).

It is interesting to notice that among the mathematicians Lévi-Strauss contacted, three had writings on game theory. This is the case of Guilbaud who made himself known to social scientists through his 45-pages review of the work by von Neumann and Morgenstern in 1949. It was also the case with Mandelbrot who was the first in France in 1952 to defend a thesis in which he provided game theoretic applications to the theory of communications and linguistics. Finally, it was the case of Schützenberger $(1949,1954)$, who established the potential contributions of game theory to psychology and psychiatry. ${ }^{16}$

Evoking the reasons that led him to game theory, Mandelbrot said: "for several years before and after my Ph.D. I was very much influenced by the examples of John von Neumann and Norbert Wiener. Indeed, Wiener's book Cybernetics and von Neumann and Morgenstern's book Theory of Games and Economic Behavior had come out, and they were very precisely what I wished to emulate one day. Each seemed to be a bold attempt to put together and develop a mathematical approach to a set of very old and very concrete problems that overlapped several disciplines" (Barcellos 2008, 218). This motivation was actually shared by all mathematicians that LéviStrauss contacted. They were all interested in these new field emerging from mathematics in the

\footnotetext{
${ }^{15}$ This corresponds to a letter from Lévi-Strauss dated 9 January 1952.

${ }^{16}$ Note that Schützenberger obtained a doctorate in medicine in 1949 and a thesis in mathematics in 1953 (under the title "Contributions aux Applications Statistiques de la Théorie de l'Information", i.e. "Contributions to Statistical Applications of Information Theory"). This explains why some of his early work were published in medical journals.
} 
United States (i.e. cybernetics, game theory and information theory) and which made it possible to go beyond the restricted framework of pure mathematics from the French school of mathematics. Applications they envisioned for communication and language favored their proximity with Lacan (who affirmed at a seminar on the $16^{\text {th }}$ of November 1955 that "the unconscious is a language" (1997 [1981], 11) ${ }^{17}$. These mathematicians also collaborated with researchers in social sciences ${ }^{18}$ and were the initiators of interdisciplinarity, an approach inaugurated in the United States, aiming at reconciling academic disciplines. ${ }^{19}$

Although Lévi-Strauss did much to bring these mathematicians together around him, there is no doubt that it was Lacan who benefited the most from it. ${ }^{20}$ In particular, he forged close relationships with Guilbaud and Riguet. Riguet (2011) reports that his meeting with Lacan took place at the interdisciplinary seminar that Lévi-Strauss organized during the years 1953-1954. It responded to his "desire to meet a theoretical and practical psychoanalyst" (Riguet 2011, 98). It also responded to a request from Lacan who, to mark his interest in formalization, entrusted Riguet with a copy of his 1945 article. The rapprochement with Lacan led Riguet, on the one hand, to follow Lacan's seminar from 1954 to 1958 (date of his departure to Zurich to work for IBM) and, on the other, to become his mathematics advisor (Nessah et al. 2021). On his side, Lévi-Strauss

\footnotetext{
${ }^{17}$ Add that Lacan later refined his position to argue that "the unconscious is structured like a language" in his seminar on January 22, 1964 (Lacan, 1998 [1973], 20).

${ }^{18}$ For example, Mandelbrot co-edited the book Etudes d'Epistémologie Génétique vol. II with Piaget and the philosopher Leo Apostel. Schützenberger's contributed in 1963 with the linguist Noam Chomsky, to the new field of free language context by developing the famous Chomsky-Schützenberger theorem.

${ }^{19}$ It is interesting to note that at the same time, social scientists and mathematicians in the United States developed similar interdisciplinary research initiatives. For example, in 1952, in Santa Monica, a two-month seminar supported by the Ford Foundation, the RAND Corporation, the Office of Naval Research and the Cowles Commission, was devoted to "The Design of Experiments in Decision Processes" on the initiative of Clyde Coombs, a psychologist, and the mathematician Robert M. Thrall. This seminar brought together psychologists (as, among others, Leon Festinger, David Beardslee and William Estes), mathematicians (as for instance, von Neumann, John Nash, Merrill M. Flood and Frederick Mosteller and Lloyd S. Shapley) and economists (as among others, Morgenstern, Jacob Marschak, Howard Raiffa, Gérard Debreu, Roy Radner and Herbert Simon) (Thrall et al. 1954). Guilbaud, Mandelbrot, Riguet and Schützenberger were all the more in favour of interdisciplinarity that they were familiar with these different initiatives they took as examples to be followed.

${ }^{20}$ None of Lévi-Strauss projects were successful (with Schützenberger and Guilbaud) or took shape (with Mandelbrot and Riguet). For example, in his letter of March 19, 1951, in which he mentions his collaboration with Schützenberger, he states: "we have difficulty finding a common language" (Jakobson and Lévi-Strauss 2018, 137).
} 
had difficulty in appropriating mathematics. As he later confessed in an interview with Guilbaud for the weekly L'Express on the $8^{\text {th }}$ of June 1961: "If you give me a problem, let me put it in a formula, I understand the formula, but after the third operation, I forget what the symbols represent, and I am no longer able to reason about the formula"21.

The influence of these mathematicians on Lacan materialized as early as September 1953 with the Rome Report (which was published in 1956 under the title "Fonction et Champ de la Parole et du Langage en psychanalyse", i.e. "Function and Field of Speech and Language in Psychoanalysis") where Lacan, by emphasizing language in psychoanalysis, explicitly refers to game theory. ${ }^{22}$

The explanations Lacan puts forward in his report enable him to clarify the direction he wishes to develop as well as the method he wishes to apply: game theory. In particular, he writes: "But mathematics can symbolize another kind of time, notably the intersubjective time that structures human action, whose formulas are beginning to be provided by game theory, still called strategy, but which it would be better to call stochastics" (2006c [1966], 237) ${ }^{23}$. This evocation of game theory is immediately associated with his 1945 article, to which he returns for the first time, stating: "The author of these lines has attempted to demonstrate in the logic of a sophism the temporal mainsprings through which human action [...] gives the other's action[...] its direction to come. [...] This example indicates how the mathematical formalization [...] can bring to the science of human action the structure of intersubjective time that psychoanalytic conjecture needs to

\footnotetext{
${ }^{21}$ Cited in Denis Bertholet (2008, 275).

22 This report was primarily a response to the criticisms addressed by some of his colleagues at the Société Psychanalytique de Paris (Paris Psychoanalytical Society; SPP hereafter) about his practice of psychoanalysis with patients. He eventually resigned from the SPP in June 1953 and joined a new institution called the Société Française de Psychanalyse (French Society of Psychoanalysis), created the same year by two other resignees, Daniel Lagache and Françoise Dolto. He will be followed by André Berge who, by the greatest coincidence, will see the same year, his son Claude Berge defend a doctorate in mathematics entirely devoted to game theory entitled Sur une Théorie Ensembliste des Jeux Alternatifs ("On a Set Theory of Sequential Games"). The thesis will be immediately published as it stands in the Journal de Mathématiques Pures et Appliquées (Berge, 1953b).

${ }^{23}$ In the French version, see Lacan $(1966,287)$.
} 
ensure its own rigor" (2006c [1966], 237-238) ${ }^{24}$.

These comments prompt several remarks. First, Lacan is now aware of the importance of his mode of reasoning and its link with game theory. Second, he insists on the notion of "intersubjective time" which he sees as the key element of his reflection and the crux of decision. Lacan defines intersubjective time as that moment when interaction (between individuals) takes place. That is, the moment when decision-making occurs and everything is at stake, making essential the study of this notion. Third, Lacan finds that mathematical formalization is the means for psychoanalysis to rigorously capture intersubjective time.

Note that Lacan assimilates game theory to a stochastic theory. Everything indicates that by the term "stochastic", he refers to the minimax theorem (in mixed strategies). Recall that this theorem was first introduced by von Neumann in 1928 and taken up in the Theory of Games and Economic Behavior on the basis of a totally different demonstration. The theorem concerns zero-sum games with two players, i.e. games for which the gains of a player correspond to the losses of the other. Considering that players have a finite number of pure strategies (i.e. deterministic strategies), von Neumann shows that there is a strategy that ensures each individual a minimum gain, whatever the choice of the other. This strategy, called minimax, is the one that makes the other's maximum gain minimum and must be chosen according to a random process. A strategy that prescribes the selection of a pure strategy by means of a random process is called a mixed strategy, hence the name minimax theorem in mixed strategies. ${ }^{25}$ It is this probabilistic character of the minimax theorem which seems to lead Lacan to identify game theory with a stochastic theory. This shows that he was familiar with some of the technical aspects of game theory and that the mathematicians

\footnotetext{
${ }^{24}$ In the French version, see Lacan $(1966,287)$.

${ }^{25}$ Behind the notion of mixed strategies is the idea that each individual seeks to protect himself by preventing the other from guessing his intentions.
} 
who advised him had gone far in their presentation of the work of von Neumann and Morgenstern. It also shows that Lacan took game theory seriously and that he really made an effort to take an interest in it.

One could possibly object that the term stochastic to which Lacan attaches himself while referring to mixed strategies, is to be associated with Nash's equilibrium, that is with what became the canonical concept of game theory. Remember that when Nash (1950) introduced the notion of the "equilibrium point" (later called the Nash equilibrium), he gave conditions for its existence in the case where individuals play in mixed strategies. However, it is unlikely that Lacan was aware of Nash's concept as it was not yet discussed in France. The first to mention it was Guilbaud (1954, 1955) but without measuring its importance. It was only with Robin Farquharson (1955) and Claude Berge (1957) that the "equilibrium point" was really put forward. The former by representing the preferences of the players by an order relation and providing a general definition to equilibrium, the latter offering more general existence conditions. Before Farqharson's and Berge's works, game theoretic approaches published in France were mainly based on generalizations of the minimax theorem (Kneeser, 1952; Berge, 1954; Choquet, 1955; Sion, 1957), applications of this theorem (Mandelbrot, 1952), or detailed presentations of this theorem (Ville, 1954).

\section{From the seminar on "La Lettre Volée"}

\subsection{Preliminaries}

In the mid-1950s, game theory enjoyed a positive a priori in France, notably thanks to the promotional efforts of authors such as Guilbaud, Lévi-Strauss and the economist Henri Guitton (Nessah et al. 2021). A revealing element is the constant translation of books in english on game 
theory by Dunod Publishing since 1956. It all began with John Davis Williams' book translated under the french title La Stratégie dans les Actions Humaines: les Affaires, la Guerre, les Jeux $(1956)^{26}$. The collection was next enriched with translations by Stephen Vajda, Martin Shubik, Melvin Dresher, Anatol Rapoport, and others. This may be just a detail, but it is not without interest: by translating books on game theory, Dunod opened a breach into which foreign publishing houses then rushed. After being translated into French, Williams' book was translated into Swedish in 1957, Russian in 1960, Polish in 1965, Japanese in 1967, and Hungarian in 1972. The fact that Dunod played a leading role is one element among others that shows how well game theory is received in France at the time.

However, despite this craze, applications were slow to emerge. It was exactly at this moment that Lacan caused a sensation with his seminar of April $26^{\text {th }} 1955$, known as the seminar on "La Lettre Volée”. In this seminar, Lacan returns to Edgar Allan Poe's short story, "Purloined Letter", which he analyzes from the angle of game theory. He enhances notions initially introduced by Freud, such as repetition automatism. In the history of psychoanalysis, this text by Lacan is now a classic. But it also deserves a place in the history of game theory. Indeed, as Steven Brams (2011) shows, it is now common to analyze literary texts, short stories, poems or operas using game theory. This takes on its full meaning when, in the work under consideration, the question is whether the calculations made by the literary characters can explain their behavior. In an analysis of 39 game theoretic analysis of literary works, Brams (2011) attributes the first game theoretic analysis of Poe's short story to the economist Morton Davis (1970). However, Lacan had preceded him, moreover, in a different and original way.

Adopting a chronological perspective over the period 1935-2009, Brams $(2011,6)$ proposes a list

\footnotetext{
${ }^{26}$ The book was initially published in English in 1954 under the title Compleat Strategyst, Being a Primer on the Theory of Games of Strategy, by McGraw Hill and then in 1966 by Dover Publications, Inc., New York.
} 
of applications of game theory to the analysis of literary works, the first 15 of which are the following:

1. Arthur Conan Doyle, Sherlock Holmes (Morgenstern, 1935; von Neumann and Morgenstern, 1944/1953; Vorob'ev, 1968)

2. William Shakespeare, The Merchant of Venice (Williams, 1954/1966)

3. William Shakespeare, Othello (Rapoport, 1960; Teodorescu-Brinzeu, 1977)

4. William Shakespeare, Measure for Measure (Schelling, 1960)

5. O. Henry (William Sidney Porter),"The Gift of the Magi" (Rapoport, 1960; Vorob'ev, 1968; Rasmusen, 1989)

6. Giacomo Puccini, Tosca (Rapoport, 1962)

7. William Shakespeare, Henry V (Schelling, 1966; Dixit and Nalebuff, 1991)

8. Joseph Conrad, The Secret Agent (Schelling, 1966)

9. Alexandre Pouchkine, Eugene Onegin (Vorob'ev, 1968)

10. William Shakespeare, Hamlet (Vorob'ev, 1968; Brams, 1994b; Howard, 1996)

11. Edgar Allan Poe, "The Purloined Letter" (Davis, 1970).

12. Harold Pinter, The Caretaker (Howard, 1971)

13. William Shakespeare, Richard III (Lalu, 1977)

14. Agatha Christie, The Mousetrap (Steriadi-Bogdan, 1977)

15. Homer, The Odyssey (Elster 1979; Mehlmann, 2000).

If Lacan's treatment of Poe's short story was included, it goes without saying that it would figure prominently as an extension of von Neumann and Morgenstern. Again, many of those who referred to this seminar have never situated it in the light of the history of game theory. They do not insist on the fact that it is one of the first application of game theory in social sciences and none noted that this application dated from 1955 or that it was first published in $1957 .{ }^{27}$ As a matter of fact, most authors quote the 1966 work, Écrits, while it is mentioned on page 918 of this book that the seminar on "La Lettre Volée" was presented on April 26"t , 1955. It was written up (and dated in Guitrancourt and San Casciano) between mid-May and mid-August 1956. Published in La Psychanalyse, vol 2, 1957, p. 1-44)"28.

\footnotetext{
${ }^{27}$ This is true for almost all authors quoting the seminar on "La Lettre Volée", including Plon (1976), Charraud (1997) or Cléro (2008). Note that Daniel Read (2020) refers to the seminar on "La Lettre Volée" quoting a paper published in 1972. This corresponds to a translated version published in the journal Yale French Studies. Read says little about the content of the paper and only states that: "Lacan's analysis does not resemble game theory as it currently stands, and is not described here (in fact, I could not describe it)" (Read 2020, 399). It is clear that if Lacan's work is presented in these terms one cannot see what makes it original, and this does not help the diffusion of his ideas.

${ }^{28}$ Only Régis Deloche and Fabienne Oguer (2006, p. 99) install Lacan in the literature by evoking the odd and even game by writing: "Guilbaud [1949; 1954, Ch. Ill; 1997], Lacan [1966], Davis [1970] and Brams [1994a; 1994b] analyzed this game", but without specifying what makes the originality of his study and by referring (as it is usual) to the 1966 work.
} 
As for game theory, it is common in the field of psychoanalysis (and psychiatry) to study masterpieces of the literature. Freud very quickly dedicated himself to this task by studying Hoffmann's tale, The Man in Sand, and Shakespeare's works, The Merchant of Venice and King Lear. The seminar on "La Lettre Volée" takes part in this tradition. But strangely, in the version which appears in Écrits, Lacan gave no information on the reasons which led him to be interested in the short story by Poe. He indicates that the poet Baudelaire promoted the first French translation of it but he does not explain the reasons underlying his focus on Poe's novel. If Lacan could not ignore that Marie Bonaparte had devoted a book ${ }^{29}$ to Poe in which she studied, from the angle of psychoanalysis, the life and work of the author, he neither quotes nor mentions her. ${ }^{30}$ Lacan neither refers to Guilbaud whom we know, was very close to him since he was one of his principal mathematical advisers. However, in his 1949 review of von Neumann and Morgenstern's book, Guilbaud used Poe's short story to illustrate the notion of mixed strategies in a section entitled "La Ruse" ("The Cunning"). While supporting the example of von Neumann and Morgenstern, who, to illustrate this same notion, had used a scene by Conan Doyle's Sherlock Holmes, Guilbaud took up a scene from Poe's short story in which the odd or even game intervenes. Guilbaud's reference to a work other than that borrowed by von Neumann and Morgenstern sought to show that one could find in the characteristics of a fiction (that borrowed by von Neumann and Morgenstern) the characteristics of a "real" game such as the odd or even game, hence an analytical treatment that could be analogous. Then, it implicitly meant that game theory could provide a reading grid for a range of literary works. In his course, which he published

\footnotetext{
${ }^{29}$ This book published in 1933 devoted a short section to "La Lettre Volée" on pages 601-602.

${ }^{30}$ It was much later, during his seminar on March $10^{\text {th }}, 1965$, that Lacan, without mentioning the name of Marie Bonaparte returned to describe her study of Poe's short story as being "pseudo-analytic lucubrations" (Lacan, 1965, 115). However, we cannot ascertain that this assessment is worth of interest as Lacan's view of Marie Bonaparte was negatively biased. Lacan always resented her for being among those who criticized his practice of psychoanalysis and thus contributed to his departure from the SPP in 1953.
} 
in 1954 , he identically reproduced his analysis of Poe's short story in a section now entitled “Cunning, Bluff and Strategies".

Finally, Lacan did not either quote Schützenberger (1949). However, in putting game theory into perspective, that last briefly evoked Poe's short story after presenting the minimax strategy. He did not speak explicitly of the odd or even game but the few lines he devoted to it allow us to understand that it is this game that he was referring to. Commenting on von Neumann and Morgenstern's works, he wrote: "The scope of these considerations goes far beyond that of a pure and simple formatting: there is first of all the solution to this infinite recurrence, a real elite paradox, to which Edgard Poe's player would be led if he met an opponent of his size" (Schützenberger 1949, 597). To this sentence, he associated a footnote where he gave an explanation of what he meant by the solution to the problem dealt with by Poe.

It is in 1978, with the publication of Le Séminaire - Livre II, that one can realize that Lacan had not arrived by himself at Poe's short story. Comparing Le Séminaire - Livre II and Écrits, we observe that in this last work, Lacan modified the presentation of his seminar on "La Lettre Volée", minor modifications but which gave the impression that he was the first in France to make reference to Poe. Le Séminaire - Livre II originates from Lacan's son-in-law, Jacques-Alain Miller. The book is a compilation of Lacan's articles from the original transcriptions of his seminar held from the $17^{\text {th }}$ November 1954 to June $29^{\text {th }} 1955$, among which we count the seminar on "La Lettre Volée". We learn from those transcriptions that Lacan's interest in Poe was inspired by cyberneticians: "A short text comes to our aid, from Edgar Poe, which the cyberneticists, I noticed, make something of. This text is in The Purloined Letter, an absolutely sensational short story, which could even be considered as essential for a psychoanalyst" (Lacan, 1988 [1978], 179). Through his reference to cyberneticians, Lacan gives us a lead about how he arrived at Poe's story. But this lead remains vague as both Guilbaud, Mandelbrot and Schützenberger were all 
members of the Cercle d'Etudes Cybernétiques (Cybernetic Studies Circle) whose existence, stretching from 1950 to 1953, was of short duration.

It is finally in an article by Guilbaud (1953) that we find the most convincing information. Referring to cunning and bluffing, Guilbaud points out that Poe was the first to attempt an analysis of the even or odd game. While he argues that this analysis was clumsy, Guilbaud adds in a footnote that to study the even or odd game does not resort to psychology but to logic as Lacan in his 1945 article. This shows that Guilbaud was perfectly aware of the contents of the 1945 article. It is, in fact, likely that Lacan had informed him of a copy, as he did with Riguet in order to assert his interest in modelling. In his article, Guilbaud recommends using Lacan's mode of reasoning in order to analyze the even or odd game and this is what does Lacan himself in his seminar on "La Lettre Volée". This supports the idea that Guilbaud is the one who inspired Lacan in the choice of Poe's work, especially as he often referred to Poe's short story and the odd or even game in his works.

\subsection{The even or odd game}

Poe's story is articulated around two scenes, each of them about a theft. The first scene, which Lacan identifies with the primal scene, takes place in the royal boudoir in the presence of three characters: the king, the queen and Minister D. Under the eyes of the queen, Minister D. steals a letter on a table which that seems compromising for the queen given her confusion and her fear of awakening the king's attention. It is then that Mr G., prefect of police of Paris, is solicited to recover the letter. Despite multiple searches that he and his men organized in the Minister's private mansion (over a period of eighteen months), the letter was not found. Faced with these repeated failures, the prefect takes the initiative of contacting Detective Dupin to propose the following arrangement: if he recovers the letter, he will obtain a strong reward. 
From the second scene, we learn that Dupin has succeeded in taking up the letter. To do so, he invited himself to the minister's house and, as he crept into his room, noticed a crumpled letter on the mantel that convinced him that it was the letter he was looking for. As Lacan (2006a [1966], 9) writes, "His conviction is reinforced by the very details which seem designed to contradict the description he has been given of the stolen letter, with the exception of the size, which fits" ${ }^{\text {31 }}$. He then took it, and rightly so, since it was indeed the compromising letter. The police, for their part, were not interested in this letter that they had seen but which, appearing abandoned because crumpled, did not give the impression of being a letter of great importance. To justify his choice, Dupin says he was inspired by a child prodigy who won every time he played odd or even. When asked how he guessed whether the objects his opponent was hiding in his hand were even or odd in number, the child replied: "After a round won or lost by me [...], I know that if my opponent is a simpleton, "his amount of cunning" will not exceed the change from even to odd, but if he is "a simpleton a degree above the first," it will cross his mind that I will think of that myself and hence that it makes sense for him to play even again" (Lacan, 2006a [1966], 43) ${ }^{32}$. It is by identifying with his partners that the child wins every time, a strategy that Dupin has taken up with Minister D. to find the letter ${ }^{33}$.

Since the odd or even game is the crux of the problem, let us analyze it. This zero-sum game involves two individuals. Assuming a marble game, it proceeds as follows: one of the individuals (we call the partner) takes marbles in one hand. The other individual (we call the child prodigy) has to say whether the number of marbles contained in the hand of the partner is even or odd. If

\footnotetext{
${ }^{31}$ In the French version, see Lacan $(1966,14)$.

${ }^{32}$ In the French version, see Lacan $(1966,58)$.

${ }^{33}$ It is through the child prodigy's mode of reasoning that Guilbaud and Schützenberger became interested in "La Lettre Volée", and this can easily be understood given the mathematical dimension underlying it. Nevertheless, it should also be noted that the translator from Poe in France, Charles Baudelaire, helped to highlight this way of thinking. Indeed, having been himself fascinated by this mode of reasoning, he echoed it by repeating word for word the child's argument in his work published (posthumously) in 1869, L'Art Romantique (see pages 274-275).
} 
his answer is correct, he wins a ball, if he is wrong, he loses a ball. In other words, the game is such that the partner has two pure strategies: holding in his hand an even number of balls $(\mathrm{P})$ or an odd number of balls (I). Similarly, the child prodigy has two pure strategies: even (P) or odd (I). The game can be summarized by the payoff matrix described in figure 1, which is better known in game theory as matching pennies.

\begin{tabular}{cccc} 
& & \multicolumn{2}{c}{ Child prodigy } \\
& & $\mathrm{P}$ & $\mathrm{I}$ \\
& & & \\
Partner & $\mathrm{P}$ & $-1,1$ & $1,-1$ \\
& $\mathrm{I}$ & $1,-1$ & $-1,1$
\end{tabular}

Figure 1.

Consider the partner is the row player and the child prodigy is the column player. An element of the matrix (i.e. a box of the table) represents an outcome of the game: respectively the gain of the partner and the gain of the child prodigy. If, for example, the partner has an even number of marbles in his hand and the child prodigy announces an odd number, the partner wins a marble (1) at the expense of the child prodigy (-1). We must add that in addition to the two pure strategies each of the protagonists has a large number of mixed strategies, i.e. each of them can choose a pure strategy at random. More precisely, the partner (resp., child prodigy) can choose an even number of marbles with a probability $\alpha$ (resp., $\beta$ ) and an odd number of marbles with a probability 1- $\alpha$ (resp., 1- $\beta$ ), where $0 \leq \alpha \leq 1$ (resp., $0 \leq \beta \leq 1)$.

According to Poe, the child prodigy would win every time because of his ability to identify with his partner. However, for Lacan, this strategy is a subterfuge whose sole purpose is to circumvent the impasse to which the game would lead both players. But before we focus on his analysis of the game, let us see how it differs from Guilbaud $(1949,312) .{ }^{34}$ For this last, when the child plays

\footnotetext{
${ }^{34}$ Lacan sees in Poe "a fine precursor of research into combinatorial strategy" (2006a [1966], 46).
} 
with the same partner for several periods, "the experience helping [the child and his partner] arrive at an equal power of reflection". Here there is the idea that by repeating the game long enough, the partner must eventually be able to understand how the child plays. It is then argued that "the only solution is obviously to choose at random [...]. Thus, the choice of chance plays the role of defensive position" (Guilbaud 1949, 314). Guilbaud advances an intuition which we see, through his evocation of chance, that it rests on the recourse to mixed strategies. On one hand, Guilbaud is right in advocating the choice of mixed strategies, but on the other, his reasoning is not consistent because he underestimates the scope of those strategies. Why should the partner wait for several stages in order to play mixed strategies? It constitutes indeed a way for partners to protect themselves by creating uncertainty about their own choice, making this strategy appropriate right from the first stage of the game. Suppose that the partner chooses to play an even number of marbles with the probability $1 / 2$ and an odd number of marbles with the complementary probability. Then the child prodigy, while imitating him, would no longer be able to determine the actual choice of his partner and therefore will not be able to deduce the result. Consequently, by adopting this mixed strategy throughout the game, each of the protagonists will win, on average, in $50 \%$ of the cases. It is also the solution that Davis (1970), preceded by Schützenberger (1949), rightly advocates. As the latter writes in his footnote: “(- Stolen letter -). The game is schematized as follows: A and B choose independently even or odd. If both choices are identical, A wins. B wins else. The optimal strategy which ensures each player to win one game out of two, consists of each player to choose at random even and odd with an equal probability. The rule of the game can be modified, the coincidence of the two pieces bringing more or less to A depending on whether it was done on even or on odd; and similarly, the two possible discrepancies being penalized differently. The theory then indicates what should be the probabilities with which each player has an advantage in randomly drawing the piece side he chooses. Note that this situation is also (among others) that of the D. C. A. pointer and the pilot of the plane: there is or is not a 
coincidence of two trajectories. The pilot can choose his feint (left or right) - his opponent on the ground before guessing it”' (Schützenberger 1949, 597).

Lacan's reasoning (2006a [1966], 43-44) differ. The following quotes help us to clarify his view: "that it is through an internal imitation of his opponent's attitudes and mimicry that he claims to arrive at the proper assessment of his object. But what then of the next level, when my opponent, having recognized that I am intelligent enough to follow him in this move, will manifest his own intelligence in realizing that it is by acting like an idiot that he has his best chance of deceiving me? There is no other valid time of the reasoning in this moment, precisely because it can but repeat thereafter in an indefinite oscillation". ${ }^{35}$ Lacan (2006a [1966], 44) adds: "And apart from the case of pure imbecility, in which the reasoning seemed to be objectively grounded, the child cannot but think that his opponent will arrive at the obstacle of this third time since he granted him the second, by which he himself is considered by his opponent to be a subject who objectifies him"36.

In Lacan's logic, the child may always win if his partner is fundamentally "stupid", that is if he is not able to follow the child's reasoning. But this relates to a situation far too exceptional to claim generality. A partner acting stupidly in the first round may well follow the child's reasoning afterwards. It would then no longer be possible for them to make choices, as they would be locked in a perpetual movement of conjecture, an indefinite oscillation. Lacan evokes here a common knowledge reasoning and comes to reduce this game to what it is, that is a game where there is no solution (in pure strategy). Lending the child prodigy extraordinary capacities to extract him from this perpetual movement of conjectures and find a solution to the problem is thus for Lacan nothing more than a subterfuge to pretend to give an end to the story where in reality there is none.

\footnotetext{
${ }^{35}$ In the French version, see Lacan $(1966,58)$.

${ }^{36}$ In the French version, see Lacan $(1966,58)$.
} 
Analyzing these two antagonists positions in the light of recent development of game theory is enlightening. As Nessah et al. (2021) point out, common knowledge (of rationality) leads, as intuitively suggested by Lacan, to the conclusion that this game has no solution (in pure strategy). Indeed, regardless of the outcome of the first round, the child knows in the second round that his partner knows that he has been stupid, then he is not encouraged to play the same in the second round. But, he also knows that his partner knows that he knows it and that it is therefore in his interest to play in the second round the same as in the first round, and it continues as such indefinitely. It follows that if we are in a situation of common knowledge (of rationality), Poe's solution is de facto a subterfuge.

Note that recent developments in game theory and level-k reasoning in particular, gives credits to Poe's argument. Assume that we are not in a situation of common knowledge but merely of levelk reasoning where rationality of players is bounded (Stahl and Wilson 1994, 1995; Nagel 1995). Considering as Poe that the partner is either naïve (meaning that he changes his choice after the first round) or is a simpleton a degree above the first, that is a level-1 player who knows the child prodigy is rational and anticipate with a level-1 his anticipation, then the child prodigy who is assumed to be able to perfectly identify the level $k$ of knowledge of the other (meaning that the child is of level $k+1$ ), will always play the adequate best reply. Poe's strategy can then be interpreted as a level-k reasoning ${ }^{37}$ and if this not certain that Poe would agree with this interpretation, it shows that there are several ways of apprehending the stakes that he has opened up and that Lacan's perspective is one among others to come ${ }^{38}$.

\footnotetext{
${ }^{37}$ Note that explicitly motivating their study on Poe's child prodigy, Kfir Eliaz and Ariel Rubinstein (2011) found experimentally a higher probability of winning for the guessing player

${ }^{38}$ Read (2020) provides an overview of the different analyses of the child prodigy argument that have been proposed since the 1970s.
} 
Add that Lacan's interest in Poe's story is not bounded to the analysis of the odd or even game. Unlike his predecessors, he analyzes the novel in its entirety. In particular, he points out that the two scenes of the novel are structured in the same way, each being built around three perspectives of the characters involved.

There is the look that sees nothing (the king in the first scene, the police in the second), the look that sees that the first sees nothing and thinks that the letter risks nothing (the queen and Minister D.) and finally, the look that sees that what wants to be hidden is precisely presented openly (Minister D. and then Dupin). This leads Lacan to note that the behaviour of the various characters is determined by the place they occupy in relation to the letter. As he states, "the signifier's [i.e., the purloined letter] displacement determines subjects' acts, destiny, refusals, blindnesses, success, and fate, regardless of their innate gifts and instruction, and irregardless of their character or sex" (Lacan, 2006a [1966], 21) ${ }^{39}$. Given the importance of the letter, it can therefore be considered as the main character. Thus, we can see that, consciously or unconsciously, Poe made strategic use of the figure of Dupin. By characterizing him with superior identification skills than others, he managed to make him stand out to the reader as the hero of the story, while the real main character is the letter (the content of which being completely unknown).

Overall, we should advocate that Lacan took the measure of his mode of reasoning, to the point of applying it by dissociating himself from the analyses of Guilbaud (1949) and Schützenberger (1949). He was therefore sufficiently convinced of the relevance of his mode of reasoning to think that he was in a position to propose an original analysis. He, who identified game theory with stochastic theory, will never use mixed strategies, preferring his own mode of reasoning. Perhaps

\footnotetext{
${ }^{39}$ In the French version, see Lacan $(1966,30)$.
} 
that is why he will later put forward a new interpretation of game theory in "La Science et la Vérité" ("Science and Truth"). He will no longer refer to it as a stochastic theory but as a theory, "better called strategy, which takes advantage of the thoroughly calculable character of a subject strictly reduced to the formula for a matrix of signifying combinations" (Lacan, 2006d [1966], $730)^{40}$.

\section{Conclusion}

Not evoking his structuralist commitment or the originality of his contributions to psychoanalysis, this paper sheds light on Lacan's contribution to strategic reasoning and common knowledge in the analysis of games.

We argue that the guiding thread running through Lacan's discovery and early contribution to game theory is his mode of reasoning initially presented in an original paper published in 1945, the same article that he proposed to Riguet and Guilbaud to convince them of his desire to know more about mathematical formalism. In contact with these mathematicians, Lacan realized that what he initially considered to be a problem of logic hid a mode of reasoning that opened up new perspectives because it lent itself to systematization. This awareness led him to further focus on this mode of reasoning in the seminar on "La Lettre Volée". Working at the time as a liberal psychoanalyst and being outside of academic institutions, Lacan surrounded himself with the mathematicians most able to help him go beyond his own limits when many feared that the use of mathematics would distort their discipline.

Lacan started among the first interdisciplinary work at the crossroad between mathematics and social sciences and if he remains unknown to most game theorists, his work inspired some French

\footnotetext{
${ }^{40}$ In the French version, see Lacan $(1966,860)$.
} 
mathematicians interested in game theory. This is the case, for example, of Jean-Michel Lasry (1984) who, before being one of the initiators of the theory of mean-field games, had come to game theory through his interest in common knowledge. His first article on the subject was a mathematical presentation of common knowledge in which he evoked in a few lines the enigma of the three prisoners while proposing logical foundations to Lacan's notion of "(big) other". It is then no coincidence that this article was published in the psychoanalytical journal Ornicar. Similarly, quoting the seminar on "La Lettre Volée", Pierre Levine (1980) acknowledged the possibilities offered by psychoanalysis as a field of application for game theory. This led him to build a mathematical model of the unconscious in which he relied on a formalism that he introduced and developed in his doctoral thesis defended in 1979. This resulting formalism corresponds to what he called games with strategic presuppositions. ${ }^{41}$

With the growing development of epistemic game theory since the 1970s, Lacan's contribution on specularity reasoning in games and common knowledge applications deserves to be acknowledged beyond.

\section{Acknowledgements}

We thank the editor and our three anonymous referees for their excellent and constructive comments. We would also like to present our gratitude to Denis Bouyssou, Jean-Louis Chassaing, Bertrand Crettez, Régis Deloche, Antoine Missemer, Olivier Musy, Emmanuel Petit, Philippe Quirion, Gilles Rotillon, Elisabeth Roudinesco, Christian Schmidt, Philippe Solal, and Manon Thobois for their inspiring and insightful remarks on earlier versions of this paper. T. Tazdaït acknowledges the support from Campus France (Cèdre research project No. 42315RA). Obviously, all the remaining errors are ours.

\section{References}

Apostel, L., B. Mandelbrot, and J. Piaget. 1957. Etudes d'Epistémologie Génétique vol. II : Logique et Equilibre. Paris: Presses Universitaires de France.

\footnotetext{
${ }^{41}$ Again, and conforming with all authors quoting Lacan's work on the topic, both Lasry and Levine did not refer to Lacan original works but to Écrits.
} 
Aumann, R.J. 1976. Agreeing to Disagree. Annals of Statistics 4: 1236-1239.

Barcellos, A. 2008. Interview of B. B. Mandelbrot. In Mathematical People: Profiles and Interviews, edited by D.J. Albers and G.L. Alexanderson, 213-234. Wellesley: A.K. Peters (second edition).

Baudelaire, C. 1869. Oeuvres Complètes III : L’Art Romantique. Paris: Michel Lévy Frères éditeurs.

Benveniste, E. 1947. Le Jeu comme Structure. Deucalion 2: 161-167.

Berge C. 1953a. Sur une Théorie Ensembliste des Jeux Alternatifs. PhD dissertation, Université de Paris

Berge C. 1953b. Sur une Théorie Ensembliste des Jeux Alternatifs. Journal de Mathématiques Pures et Appliquées 32: $129-184$

Berge C. 1954. Sur une Convexité Régulière Non Linéaire et ses Applications à la Théorie des Jeux. Bulletin de la Société Mathématique de France 82: 301-315.

Berge, C. 1957. Théorie Générale des Jeux à n Personnes. Paris: Gauthier Villars.

Bertholet, D. 2008. Claude Lévi-Strauss. Paris: Odile Jacob.

Billot, A. 2008. Le Raisonnement Spéculaire (Ce que Aumann Doit à Lacan). In Economie et Cognition, edited by B. Walliser, 115-146. Paris: Maison des Sciences de l'Homme.

Brams, S. J. 1994a. Game Theory and Literature. Games and Economic Behavior 6 (1): 32-54

Brams, S. J. 1994b. Theory of Moves. Cambridge: Cambridge University Press

Brams, S.J. 2011. Game Theory and the Humanities: Bridging Two Worlds. Cambridge MA: MIT press.

Bonaparte, M. 1933. Edgar Poe. Etude Psychanalytique. Paris: Denoël et Steele.

Boyd, J. 1969. The Algebra of Group Kinship. Journal of Mathematical Psychology 6(1): 139-167.

Bush, R.R. 1963. An Algebric Treatment of Rules of Marriage and Descent. In An Anatomy of Kinship., edited by H.C. White, 159-162. Englewood Cliffs: Prentice Hall.

Caillois, R. 1946. Le Ludique et le Sacré. Confluences 10: 66-77.

Caillois, R. 1958. Les Jeux et les Hommes : le Masque et le Vertige. Paris: Gallimard.

Charraud, N. 1997. Lacan et les Mathématiques. Paris: Anthropos.

Chomsky, N., and M.-P. Schützenberger. 1963. The Algebraic Theory of Context-Free Languages. In Computer Programming and Formal Systems, edited by P. Braffort and D. Hirschberg, 118-161. Amsterdam: North Holland.

Choquet, G. 1955. Sur le Théorème des Points-Selle de la Théorie des Jeux. Bulletin des Sciences Mathématiques, 79: $48-55$

Cléro, J.-P. 2008. Lacan and Probability. Electronic Jouranl for History of Probability and Statistics 4(2): $297-319$.

Courrège, P. 1965. Un modèle Mathématique des Structures Elémentaires de Parenté. L'homme 5(3-4): 248-290.

Davis, M.D. 1970. Game Theory: A Nontechnical Introduction. New York: Basic.

Deloche, R., and F. Oguer. 2006. Game Theory and Poe's Detective Stories and Life. Eastern Economic Journal 32(1): 97-110.

Dixit, A. K., B. J. Nalebuff 1991. Thinking Strategically: The Competitive Edge in Business, Politics, and Everyday Life. New York: Norton. 
Dupuy, J.-P. 1989. Convention et Common Knowledge. Revue Economique 40(2): 361-400.

Eliaz, K., and A. Rubinstein. 2011. Edgar Allan Poe's Riddle: Framing Effects in Repeated Matching Pennies Games. Games and Economic Behavior 71(1) : 88-99.

Elster, J. 1979. Ulysses and the Sirens: Studies in Rationality and Irrationality. Cambridge: Cambridge University Press.

Farquharson, R. 1955. Sur une Généralisation de la Notion d’Equilibrium. Comptes Rendus des Séances de l'Académie des Sciences 240: 46-48.

Friedell, M.F. 1967. On the Structure of Shared Awareness, Working paper $n^{\circ} 27$, the Center for Research on Social Organizations, University of Michigan.

Friedell, M.F. 1969. On the Structure of Shared Awareness. Behavioral Science 14(1): 28-39.

Gamow, G., and M. Stern. 1958. Puzzle Math. New York: The Viking Press.

Geanakoplos J. (1994). Common Knowledge. In Handbook of Game Theory with Economic Applications, Volume 2 , edited by R. Aumann and S. Hart, 1437-1496. Amsterdam: Elsevier.

Guilbaud, G.-T. 1949. La Théorie des Jeux : Contribution Critique à la Théorie de la Valeur. Economie Appliquée 2: 275-319.

Guilbaud, G.-T. 1953. Pilotes, Stratégies et Joueurs. Structure et Evolution des Techniques 5(35-36): 34-46

Guilbaud, G.-T. 1954, Leçons sur les Eléments Principaux de la Théorie Mathématique des Jeux. In Stratégies et Décisions Economiques. Etudes Théoriques et Applications aux Entreprises, edited by Centre d'économétrie. Paris: Centre National de la Recherche Scientifique.

Guilbaud, G.-T. 1955, La Théorie des Jeux. Revue d'Economie Politique 65 (2), 153-188.

Harman, G. 1977. Review of Linguistic Behavior by Jonathan Bennett. Language 53(2): 417-424.

Howard, N. 1996. Negotiation as Drama. How Games Become Dramatic. International Negotiation 1 (1): $125-152$.

Howard, N. 1971. Paradoxes of Rationality: Theory of Metagames and Political Behavior. Cambridge, MA: MIT Press

Huizinga J. 1951 [1938]. Homo Ludens. Essai sur la Fonction Sociale du Jeu. Paris: Gallimard.

Jakobson, R., and C. Lévi-Strauss. 2018. Correspondance 1942-1982. Paris: Seuil.

Kneser, H. (1952). Sur un Théorème Fondamental de la Théorie des Jeux. Comptes Rendus des Séances de l'Académie des Sciences 234: 2418-2420.

Koessler, F. 2000. Common Knowledge and Interactive Behaviors: A Survey. European Journal of Economic and Social Systems 14(3): 271-308.

Lacan, J. 1945. Le Temps Logique et l'Assertion de Certitude Anticipée. Un Nouveau Sophisme. Les Cahiers d'Art, $32-42$.

Lacan, J. 1946. Le Nombre Treize et la Forme Logique de la Suspicion. Les Cahiers d'Art, 389-393.

Lacan J. (1965), Problèmes Cruciaux de la Psychanalyse, Séminaire 1964-1965, http://staferla.free.fr/S12/S12\%20PROBLEMES.pdf

Lacan, J. 1966. Écrits. Paris: Seuil.

Lacan, J. 2006a [1966]. Seminar on “The Purloined Letter". In Écrits. The First Complete Edition in English, translated by B. Fink, 6-48. New York: W.W. Norton and Company. 
Lacan, J. 2006b [1966]. Logical Time and the Assertion of Anticipated Certainty. A New Sophism. In Écrits. The First Complete Edition in English, translated by B. Fink, 161-175. New York: W.W. Norton and Company.

Lacan, J. 2006c [1966]. The Function and Field of Speech and Language in Psychoanalysis. In Écrits. The First Complete Edition in English, translated by B. Fink, 197-268. New York: W.W Norton and Company.

Lacan, J. 2006d [1966] Sciences and Truth. In Écrits. The First Complete Edition in English, translated by B. Fink, 726-745. New York: W.W. Norton and Company.

Lacan, J. 1998 [1973]. The Seminar of Jacques Lacan. The Four Fondamental Concepts of Psychoanalysis. Book XI. Translated and edited by A. Sheridan. New York: W.W. Norton and Company.

Lacan, J. 1988 [1978]. The Seminar of Jacques Lacan. Book II: The Ego in Freud's Theory and in the Technique of Psychoanalysis 1954-1955. Translated and edited by S. Tomaselli. Cambridge: Cambridge University Press.

Lacan, J. 1997 [1981]. The Seminar of Jacques Lacan. Book III: The Psychoses. 1955-1956. Translated and edited by R. Grigg. New York: W.W. Norton and Company.

Lalu, I. 1977. Richard III: Balance and Games in the Study of Theatre, Poetics 6 (3/4): 339-350.

Lasry, J.-M. 1984. Common Knowledge. Ornicar 30: 75-93.

Lecouteux, G. 2018. Bayesian Game Theorists and Non-Bayesian Players. The European Journal of the History of Economic Thought 25(6): 1420-1454.

Leonard, R. 2012. Von Neumann, Morgenstern, and the Creation of Game Theory: From Chess to Social Science. Cambridge: Cambridge University Press.

Lévi-Strauss, C. 1949. Les Structures Elémentaires de la Parenté. Paris: Presses Universitaires de France.

Lévi-Strauss, C., and D. Eribon. 2009. De Près et de Loin. Paris: Odile Jacob (third edition).

Levine, P. 1979. Jeux avec Présupposés Stratégiques. PhD dissertation, Université Paris VI.

Levine, P. 1980. Introduction à un Modèle Mathématique de l'Inconscient. : l'Exemple de l'Homme aux Rats. Mathématiques et Sciences Humaines 71: 77-98.

Lewis, D.K. 1969. Convention: A Philosophical Study. Cambridge Mass.: Harvard University Press

Littlewood, J. E. 1953. A Mathematician's Miscellany. London: Methuen.

Mandelbrot, B. 1952. Contribution à la Théorie Mathématique des Jeux de Communication. PhD dissertation, Université de Paris.

Meszaros, J. 2012. Effect of Dictatorial Regimes on the Psychoanalytic Movement in Hungary and after World War II. In Psychoanalysis and Politics: Histories of Psychoanalysis under Conditions of Restricted Political Freedom, edited by J. Demousi and M.B. Plotkin, 79-108. Oxford: Oxford University Press.

Mehlmann, A. 2000. The Game's Afoot! Game Theory in Myth and Paradox, Providence, Rhode Island: The American Mathematical Society

Morgenstern, O. 1976 [1935]. Perfect Foresight and Economic Equilibrium. In Selected Economic Writings of Oskar Morgenstern, edited by Schotter, 169-183. New York: New York University Press.

Mosteller, F. 1965. Fifty Challenging Problems in Probability with Solutions. Reading, MA: Addison-Wesley.

Nagel, R. 1995. Unraveling in Guessing Games: An Experiment Study. American Economic Review 85(5): 13131326. 
Nash, J. 1950. Equilibrium Points in n-Person Games. Proceeding of the National Academy of Sciences USA 36: 4849.

Nessah, R., T. Tazdaït, and M. Vahabi. 2021. The Game is Afoot: The French Reaction to Game Theory in the Fifties. History of Political Economy 53(2).

Piaget, J. 1945. La Formation du Symbole chez l'Enfant. Neuchâtel - Paris: Delachaux et Niestlé.

Plon, M. 1976. La Théorie des Jeux : une Politique Imaginaire. Paris: Maspéro.

Porge, E. 2000. Jacques Lacan, Un Psychanalyste : Parcours d'un Enseignement. Toulouse: Erès

Rapoport, A. 1960. Fights, Games and Debates. Ann Arbor: University of Michigan Press.

Rapoport, A. 1962. The Use and Misuse of Game Theory. Scientific American 207 (6): 108-118.

Rasmussen, E. 1989. Games and Information: An introduction to Game Theory. Oxford: Blackwell.

Read, D. 2020. The Five Games of Mr Edgar Allan Poe : A Study of Strategic Thought in Purloined Letter. Rationality and Society 32(4): 369-401.

Reid, R. 1967. Marriage Systems and Algebraic Group Theory: A Critique of White's An Anatomy of Kinship. American Anthropologist 69(2): 171-178.

Riguet, J. 2011. Une analyse Indolore (propos recueillis par Deborah Guterman-Jacquet), Le Diable Probablement 9: $98-102$.

Roudinesco, E. 2010. Histoire de la Psychanalyse en France - Jacques Lacan. Paris: Livre de Poche.

Schelling, T. 1960. The Strategy of Conflict. Cambridge, MA: Harvard University Press.

Schelling, T. C. 1966. Arms and Influence. New Haven: Yale University Press

Schiffer, S. 1972. Meaning. Oxford: Oxford University Press.

Schützenberger, M.-P. 1949. A Propos de la Cybernétique (Mathématiques et Psychologie). L'Evolution Psychiatrique 4: 585-607.

Schützenberger, M.-P. 1953. Contributions aux Applications Statistiques de la Théorie de l'Information. PhD dissertation, Université de Paris.

Schützenberger, M.-P. 1954. A Tentative Classification of Goal-Seeking Behaviours. Journal of Mental Science 100(2): 97-102.

Sion, M. 1957. Sur une Généralisation du Théorème Minimax. Comptes Rendus des Séances de l'Académie des Sciences 244: 2120-2123.

Stahl, D.O., and P.W. Wilson. 1994. Experimental Evidence on Players' Models of Other Players. Journal of Economic Behavior and Organization 25(3): 309-327.

Stahl, D.O., and P.W. Wilson. 1995. On Players' Models of Other Players: Theory and Experimental Evidence. Games and Economic Behavior. 10(1): 218-54.

Steriadi-Bogdan, M. 1977. The Evolution of the Plot and Problems of Strategy in a Detective Play. Poetics 6 (3/4): 375-382.

Teodorecu-Brinzeu, P. 1977. A Systemic Approach to the Theatre. Poetics 6 (3/4): 351-374.

Thrall, R.M., C.H. Coombs, and R.L. Davis. 1954. Decision Processes. New York: Wiley and Sons. 
Vanderschraaf, P., and G. Sillari. 2014. Common Knowledge. In The Stanford Encyclopedia of Philosophy, https://plato.stanford.edu/archives/spr2014/entries/common-knowledge/

Ville, J.A. 1954. Leçons sur Quelques Aspects Nouveaux de la Théorie des Probabilités. Annales de l'I.H.P 14(2): 61-143.

Von Neumann, J., and O. Morgenstern. 1944. Theory of Games and Economic Behavior. Princeton: Princeton University Press.

Vorob'ev, N. 1968. Khudozhestvennoe Modelirovanie Konflickty i Theoria Igr ("Literary Conflict Modeling and the Theory of Games"). In Socruzhestvo Nauk $i$ Tainy Tvorchestva (The Close Relationship of the Sciences and the Secrets of Artistic Creation), edited by B.S. Meilakh, 348-372. Moscow: Izkustvo

White, H.C. 1963. An Anatomy of Kinship: Mathematical Models for Structures of Cumulated Roles. Englewood Cliffs: Prentice-Hall.

Williams, J. D. 1956 [1954]. La Stratégie dans les Actions Humaines : les Affaires, la Guerre, les Jeux. Paris: Dunod.

\author{
Annex : \\ Lacan's Proof for the enigma of three prisoners (Lacan, 2006b [1966], 163-165) ${ }^{42}$
}

Let us call " $A$ " the real subject who concludes for himself, and " $B$ " and " $C$ " those reflected subjects upon whose conduct A founds his deduction. One might object that since B's conviction is based on C's expectative, the strength of his conviction must logically dissipate when $\mathrm{C}$ stops hesitating; and reciprocally for $\mathrm{C}$ with respect to $\mathrm{B}$; both must thus remain indecisive. Nothing therefore necessitates their departure in the case that A is a black. Consequently, A cannot deduce that he is a white.

To this it must first be replied that B and C's whole cogitation is falsely imputed to them, for the only situation which could motivate it - the fact of seeing a black - is not, in effect, the true situation. What must be discerned here is whether, supposing this situation were the case, it would be wrong to impute this logical thought process to them. Now it would be nothing of the kind, for, according to my hypothesis, it is the fact that neither of them left first which allows each to believe he is a white, and their hesitating for but one instant would clearly suffice to reconvince each of them beyond the shadow of a doubt that he is a white. For hesitation is logically excluded for whomever sees two blacks. But it is also excluded in reality in this first step of the deduction for, since no one finds himself in the presence of a black and a white, there is no way for anyone to leave on the basis of what can be deduced therefrom.

But the objection presents itself more forcibly at the second stage of A's deduction. For if he has legitimately concluded that he is a white-positing that, had he been a black, the others would not have been long in realizing they were whites and leaving - he must nevertheless abandon his conclusion as soon as he comes to it; for at the very moment at which he is stirred into action by his conclusion, he sees the others setting off with him.

Before responding to this objection, let me carefully lay out anew the logical terms of the problem. "A" designates each of the subjects insofar as he himself is in the hot seat and resolves or fails to resolve to conclude about his own case. "B" and "C" are the two others insofar as they are objects of A's reasoning. But while A can correctly impute to the others a thought process which is in fact false (as I have just shown), he can, nevertheless, only take into account their real behavior.

If $\mathrm{A}$, seeing B and C set off with him, wonders again whether they have not in fact seen that he is black, it

${ }^{42}$ In the French version, see Lacan $(1966,199-201)$. 
suffices for him to stop and newly pose the question in order to answer it. For he sees that they too stop: since each of them is really in the same situation as him, or more aptly stated, is A insofar as [he is] realthat is, insofar as he resolves or fails to resolve to conclude about himself - each encounters the same doubt at the same moment as him. Regardless of the reasoning A now imputes to B and C, he will legitimately conclude again that he is a white. For he posits anew that, had he been a black, B and C would have had to continue; or at the very least, acknowledging their hesitation - which concurs with the preceding argument (here supported by the facts) that makes them wonder whether they are not blacks themselves - he posits that they would have had to set off again before him (it is the fact that he is black that gives their very hesitation its definite import, allowing them to conclude that they are whites). It is because they, seeing that he is in fact white, do nothing of the kind, that he himself takes the initiative; which is to say that they all head for the door together to declare that they are whites.

But one can still object that, having removed in this way the obstacle, we have not for all that refuted the logical objection - for the same objection turns up with the reiteration of the movement, reproducing in each of the subjects the very same doubt and arrest.

Assuredly, but logical progress must have been made in the interim. For this time A can draw but one unequivocal conclusion from the common cessation of movement: had he been a black, B and C absolutely should not have stopped. Their hesitating a second time in concluding that they are whites would be ruled out at this point: Indeed, a single hesitation suffices for them to demonstrate to each other that certainly neither of them is a black. Thus, if $\mathrm{B}$ and $\mathrm{C}$ have halted again, A can only be a white. Which is to say that this time the three subjects are confirmed in a certainty permitting of no further doubt or objection. 